\title{
Differentiating Among International Investment Disputes
}

\author{
Julie A. Maupin ${ }^{1}$
}

\begin{abstract}
Can investor-state arbitration tribunals, which exercise jurisdiction over limited claims involving discrete parties, render awards that deliver individualized justice while also promoting systemic fairness, predictability and coherence? The answer, I argue, is a qualified yes - provided that the methods employed are tailored to the particular characteristics of each dispute. Using three well-known investment arbitrations as case studies, I illustrate that investor-state disputes vary widely in terms of their socio-legal, territorial, and political impacts. Significant variances along these three dimensions call for a differentiated approach to investor-state dispute resolution. I outline what such an approach might look like and analyze how much room there is to implement it within the current framework of the regime. While some improvements can be made through arbitrator-led efforts in the short term, what is needed in the medium term is a systemic restructuring that funnels different classes of investor-state claims into different types of dispute resolution mechanisms that better comport with the claims' underlying characteristics.
\end{abstract}

\section{Introduction}

It is a basic truism of all legal decision-making that each case must be decided on its own terms. Failing this, there is a real risk that the parties to a particular dispute will receive no justice. Nevertheless, there is an equally basic countervailing truism inherent in the very concept of law - namely, the principle that like cases should be decided alike. Otherwise, either the legal system itself or the adjudicators who steward it will be regarded as arbitrary and unfair. International investment lawyers, like their counterparts in every other field of law, must contend with both of these norms. ${ }^{2}$ They must find sensible means of distinguishing between cases which are truly different in core respects while also recognizing similarities between cases which share certain fundamental commonalities. They must, in other words, differentiate among disputes.

\footnotetext{
${ }^{1}$ Lecturing Fellow in International Law, Duke University School of Law. Comments and criticisms welcome at: maupin@law.duke.edu. For helpful discussions at various stages of the project, I thank the book editors - in particular Zachary Douglas - as well as my fellow co-contributors to this volume and the participants in a roundtable held at Duke Law School.

${ }^{2}$ Readers will note that the starting point for this paper is fundamentally at odds with the approach taken by Thomas Schultz in his contribution to the present volume. (See Thomas Schultz, 'Against Consistency in Investment Arbitration', ch ?? in this book.) As will become evident below, I respectfully disagree with many of the premises and conclusions of that chapter. Because the two chapters were written contemporaneously, neither addresses the arguments of the other explicitly, though it is hoped that they will serve as useful counterpoints to one another.
} 
The task is easier said than done. In a legal system as vast as the international investment regime, all manner of possible disputes can arise. A foreign investor's cause of action against its host state can arise from a simple breach of contract or an outrageous instance of discriminatory treatment. The jurisdictional basis for the claim may lie in a contract, a domestic statute, a bilateral or regional treaty, or some combination of the four. Investor-state claims can be brought by individual foreign investors acting separately or by thousands acting jointly. The list of states' available defenses to investor-state claims includes contractual entitlement, public health, environmental protection, prudential financial regulation, military necessity, and everything in between. As to impact, the consequences of a particular state's maligned governmental action may fall entirely upon a single foreign investor or be felt, in both positive and negative ways, across society at large - sometimes even beyond the state's own borders. Against this backdrop, it would seem surprising if all international legal disputes between foreign investors and their host states could be resolved by adjudicators in a monolithic manner.

Happily, neither the complexity of international investment disputes nor their important societal implications has escaped the notice of commentators. In recent years, a prolific group of scholars has painstakingly documented the ways in which disputes between investors and foreign sovereigns often differ from the thousands of garden variety cross-border commercial disputes that arise every year in our globalized economy, and also from the dozens of classical public international law disputes that have been arbitrated between sovereign states over the past few centuries.

Van Harten, Schneiderman, Montt, and Schill have focused particular attention on what they term the 'public law' dimensions of contemporary investment disputes. ${ }^{3}$ They point out that determining whether and how much a sovereign must compensate a foreign investor for a reduction in profits occasioned by a generally applicable regulatory measure (think environmental, labor, or health regulations) is more akin to an administrative or constitutional law-style review of state action than it is to ordinary commercial arbitration. In parallel with this conceptually-oriented public law crowd, a second ${ }^{4}$ group of scholars and civil society advocates has raised difficult normative questions concerning the suitability of arbitration as a mechanism for resolving such highly charged 'regulatory disputes'. They express concern over the lack of legitimacy and accountability inherent in a system in which one-off panels of privately appointed arbitrators sit in judgment over states' exercise of their sovereign regulatory powers. ${ }^{5}$

\footnotetext{
${ }^{3}$ Gus Van Harten, Investment Treaty Arbitration and Public Law (2007) [hereinafter 'Van Harten - ITA and Public Law']; David Schneiderman, Constitutionalizing Economic Globalization: Investment Rules and Democracy's Promise (2008) [hereinafter 'Schneiderman - Constitutionalizing Economic Globalization']; Santiago Montt, State Liability in Investment Treaty Arbitration (2009), Stephan Schill (ed), International Investment Law and Comparative Public Law (2010); Stephan Schill, 'Enhancing the Legitimacy of International Investment Law: Conceptual and Methodological Foundations of a New Public Law Approach', 52 Virginia Journal of International Law (2011) 57 [hereinafter 'Schill - New Public Law Approach'].

${ }^{4}$ And partially overlapping, see eg the Van Harten and Schneiderman books, ibid..

${ }^{5}$ Charles N. Brower, 'A Crisis of Legitimacy', National Law Journal (7 October 2002); Ari Afilalo, 'Towards a Common Law of International Investment: How NAFTA Chapter 11 Panels Should Solve Their Legitimacy Crisis', 17 Georgetown International Environmental Law Review (2004) 51; Susan Frank, 'The Legitimacy Crisis in Investment Treaty Arbitration: Privatizing Public International Law Through Inconsistent Decisions', 73 Fordham Law Review (2005) 1521; Charles N. Brower and Stephan Schill, 'Is Arbitration a Threat or a Boon to the Legitimacy of International Law?', 9 Chicago Journal of International Law (2009) 471; Nienke Grossman,
} 
A third strand of the literature, in turn, attempts to respond to international investment law's 'public law challenge' and its corresponding 'legitimacy crisis' in a prescriptive, if perhaps sometimes idealistic, manner. Proposed solutions to the regime's problems have included major re-writes of states' existing investment treaty obligations, ${ }^{6}$ the importation of interpretive devices (like proportionality and balancing tests) from other national and international adjudicative traditions, ${ }^{7}$ and the introduction of a post-award system of review. ${ }^{8}$ The common thread among all of these proposals is the hope that they might encourage adjudicators to reach more socially and politically acceptable outcomes in individual disputes.

Most recently, the ongoing conceptual, normative, and prescriptive debates have touched off a burgeoning fourth wave of empirically grounded research which is shaping up along two basic lines of inquiry. One aims at identifying precisely who makes up the pool of international investment arbitrators, what makes them tick, and whether they are professionally equipped and personally disposed to discharge the politically fraught duties they are now assuming. ${ }^{9}$ Such sticky wicket questions arise both under the existing investment arbitration system and under many of the reform proposals presently being discussed by the regime's supporters and critics. The second line of empirical inquiry aims to determine, once and for all, whether there is even anything in the current international investment law regime worth reforming - a question usually framed in terms of the search for demonstrable benefits for host states. ${ }^{10}$

In this paper, I leave the detailed exploration of these four important waves of scholarly literature to others and focus instead on trying to connect some of the dots between them. The approach is

'Legitimacy and International Adjudicative Bodies', 41 George Washington International Law Review (2009) 101; Julia Hueckel, 'Rebalancing Legitimacy and Sovereignty in International Investment Agreements', 61 Emory Law Journal (2012) 601.

6 International Institute for Sustainable Development, 'Model International Agreement on Investment for Sustainable Development' (better known as the 'IISD Model BIT'), at: http://ces.iisc.ernet.in/envis/sdev/investment_model_int_handbook.pdf.

${ }^{7}$ William W. Burke-White and Andreas von Staden, 'Private Litigation in a Public Law Sphere: the Standard of Review in Investor-State Arbitrations', 35 Yale Journal of International Law (2010) 283; Suzanne A. Spears, 'The Quest for Policy Space in a New Generation of International Investment Agreements', 13 Journal of International Economic Law (2010) 1037, at 1040, 1043.

${ }^{8}$ ICSID Secretariat Discussion Paper, 'Possible Improvement of the Framework for ICSID Arbitration' (22 October 22 2004), Part VI.

9 Anthea Roberts, 'Clash of Paradigms: Actors and Analogies Shaping the Investment Treaty System', 107(1) American Journal of International Law (2013) 45; Michael Waibel \& Yanhui Wu, 'Are Arbitrators Political?' Working Paper, 2012 (on file with author); Sergio Puig, 'Social Capital in the Arbitration Market', 25 European Journal of International Law (forthcoming, 2014) (advance copy on file with author); Jason Cross and Sergio Puig, 'Expertise and Legitimacy in International Investment Law: Governing Access to Investor-State Arbitration', Paper presented at the annual meeting of the Law and Society Association, Hilton Hawaiian Village Resort, Honolulu, HI, (3 June 2012), at: http://www.allacademic.com/meta/p559091_index.html.

${ }^{10}$ For commentaries on what future empirical studies might usefully contribute to international investment law, see Jonathan Bonnitcha, 'The Economics of Investment Treaty Protection and the Evolving Empirical Research Agenda', Working Paper, at: http://ssrn.com/abstract=2138235; and Julie A. Maupin, 'Empirics and Opposition: What Empirical Studies Can (and Can't) Do for International Investment Law Scholarship', discussion paper for workshop on 'Political Economy of Investment Treaties,' London School of Economics (27-28 2012) (draft on file with author). For an overview of the ongoing empirical debate over the impact of international investment treaties on investment flows, see Jason Webb Yackee, 'Do Bilateral Investment Treaties Promote Foreign Direct Investment? Some Hints from Alternative Evidence', 51 Virginia Journal of International Law (2011) 397. 
bottom-up - from practice to theory - rather than the other way around. My goals are concrete and threefold: first, to highlight the diversity of characteristics exhibited by actual investor-state disputes; second, to construct a conceptual framework that organizes these diverse characteristics in a manner that sheds light on which ones are most salient and why; and third, to explore how adopting a differentiated (as opposed to one-size-fits-all) approach to investor-state dispute settlement can improve the functioning of the international investment law regime and help to obviate some - though by no means all - of the scholarly and civil society criticisms that have been levied against it.

The remainder of this chapter proceeds in four parts. Part II sets the stage with a brief introduction to the heterogeneity of investor-state disputes. Part III makes the case for differentiation as a conceptual approach to investor-state dispute resolution in light of this heterogeneity. In concrete terms, I propose that all international investment disputes be differentiated from the outset along three dimensions: the socio-legal, the territorial, and the political. I then pass three well-known disputes through the lens of my proposed differentiation analysis in Part IV. With each case study, I evaluate how much room there is within the existing confines of the regime for arbitrators to tailor their interpretive and procedural practices in response to the salient features of the particular dispute. I also point out areas in which broader systemic reforms are needed in order to empower arbitrators to do so more effectively. Part V concludes with a sketch of possible differentiated approaches to addressing some of international investment law's most troubling conundrums.

\section{The heterogeneity of investor-state disputes}

From the outset, building up a methodology of differentiation requires paying close attention to the tremendous diversity of international investment disputes and the legal instruments under which they arise. This is necessary because, as alluded to in the introduction to this chapter, the phrase 'international investment law' covers quite a bit of ground. Consider, by way of illustration, the following three instances of actual investor-state dispute resolution proceedings.

\section{A. Malaysian Historical Salvors}

In the original, contract-based version of this dispute, the basic complaint alleged that the underlying contract entitled the foreign claimant to $70 \%$ of the profits earned from the sale of all historical artifacts salvaged from a sunken marine vessel located within Malaysian territorial waters. The government of Malaysia, however, paid out only 40\%. ${ }^{11}$ The action was thus one for recovery of the difference. It is noteworthy that the legal instrument underlying the dispute (the contract) was unique to the parties, its subject matter was of concern only to them, and no one else appears to have had any involvement with or interest in any facet of the proceedings. ${ }^{12}$

\footnotetext{
${ }^{11}$ Malaysian Historical Salvors STN BHD v The Government of Malaysia, ICSID Case No. ARB/05/10, Award on Jurisdiction (17 May 2007), paras 14-16 (describing the original arbitration proceedings in Malaysia).

${ }^{12}$ For illustrative purposes I focus here on the underlying contractual dispute, not the investment treaty dispute as it was eventually lodged. The latter dispute raised different issues (such as denial of justice) under a different legal instrument (a bilateral investment treaty), and may well have presented matters of concern to an audience broader than the disputing parties themselves. It is worth remembering, however, that dozens of simple contract-based investor-state disputes are arbitrated each year. I use the underlying contract dispute from Malaysian Historical
} 
Of course, the fact that one of the disputing parties was a sovereign meant that the financial consequences of any adverse decision would lead to a modest reduction in the value of the public fisc. But as the funds in question would never even have entered the public fisc absent the salvage efforts undertaken by the claimants pursuant to the contract, there could be little concern that an award against the government would unduly burden Malaysian taxpayers.

In short, Malaysian Historical Salvors exemplifies the simplest possible type of investor-state dispute. As a straightforward commercial claim, it seems like the type of dispute it would be quite proper for an adjudicator to decide on its own terms, applying ordinary commercial dispute resolution principles. Few special concerns about the legitimacy of such a proceeding are likely to arise - provided, of course, that standard minimum requirements of procedural fairness are met and the parties' autonomous contractual stipulations are respected. ${ }^{13}$

\section{B. Suez, SGAB, \& Vivendiv Argentina}

Turning next to a second illustration, the Suez case too involved a specific contract between some foreign investors and their host state. ${ }^{14}$ Here, however, the subject matter of the contract involved the privatization of a basic public service, namely the water and sewerage system serving the city of Buenos Aires. As is by now well-known, the contract was concluded at a time when the Argentine peso was pegged at a rate of one-to-one with the US dollar. The contract hedged against the possibility of future currency devaluation by giving the concessionaires the right to calculate consumer water tariffs in US dollars and then convert them to Argentine pesos. ${ }^{15}$ When the onset of Argentina's 2000-2001 economic crisis indeed forced the government to abandon its currency board, the peso fell $70 \%$ overnight. The upshot of the contractual pass-through provision, under the circumstances, was that massive price increases were slated to render tap water unaffordable to many, if not most, of the eight million people living within the concessionaires' geographical service area. Not surprisingly, the government issued a moratorium on price increases in all basic services sectors and called for the mandatory re-negotiation of all public utility contracts. The investors responded by filing investment treaty claims against the government of Argentina, claiming compensation for the full amount of the originally stipulated US dollar rate of return.

As in Malaysian Historical Salvors, this dispute again arises out of a contractual investor-state relationship of a commercial nature. But even a cursory consideration reveals that additional

Salvors as an example simply because, unlike most contract-based disputes, the subsequent treaty-based proceedings made the underlying contractual dispute a matter of public record.

${ }^{13}$ These two elements are common to all contractual disputes. So long as there are no other parties involved in or impacted by the dispute, their satisfaction ensures that no concern about like cases being decided differently arises. Note, however, in the Malaysian Historical Salvors example, it was precisely because the investor alleged that basic requirements of procedural fairness were violated - both in the original arbitration and in subsequent Malaysian court proceedings - that the investment treaty claim cited here was later filed.

14 Suez, Sociedad General de Aguas de Barcelona S.A., and Vivendi Universal S.A. v. The Argentine Republic, ICSID Case No. ARB/03/19 and AWG Group Ltd. v. The Argentine Republic, UNCITRAL, Joint Decision on Liability (30 July 2010).

${ }^{15}$ The contract also gave the concessionaires the right to implement automatic price increases tied to the US Producer Price Index. These provisions were inserted because the concessionaires planned to finance their investment with funds borrowed abroad in US dollars, and therefore needed to be able to pay back the interest in US dollars as well. 
considerations should enter into the dispute resolution process above and beyond the basic concern for procedural fairness to the disputing parties. Common sense dictates that some account must be taken of the rights and interests of the eight million people whose access to affordable drinking water sits at the core of the complaint. The subject matter, in other words, matters a great deal.

Suppose one then expands the analysis to consider the fact that this dispute involved not only contractual claims and defenses but also bilateral treaty-based claims and defenses as well as claims and defenses based on multilateral human rights treaties and general international law. Next add in the fact that this case was merely one of 41 parallel claims brought against Argentina in consequence of its economic crisis - many of which involved public service concession contracts and the sum total of which, when taken together, reportedly exceeded the government fisc. Clearly, the universe of difficult legal and factual considerations begins to expand rapidly. For purposes of analytical perspicuity, however, it may be useful to walk this complexity back a bit and first consider some of the treaty-based complications separately, without the added entanglement of a specific investor-state contractual relationship.

\section{Victims of the Stanford Ponzi Scheme}

As a third illustration, the growing category of cases known as 'regulatory disputes' deserves attention. Such disputes fall at the extreme end of the investor-state dispute spectrum. In one of the latest examples, a group of Central American investors has submitted a notice of intent to submit an arbitration claim against the US government under the Dominican Republic-Central America-United States Free Trade Agreement (DR-CAFTA). ${ }^{16}$ The basic allegation is that the Texas branch office of the US Securities and Exchange Commission (SEC) repeatedly declined to expose, regulate, or break up a Texas-based Ponzi scheme due to the fact that most of the scheme's investors were not US citizens. ${ }^{17}$ This nationality-based discrimination, the notice alleges, caused the Central American investors to suffer massive losses, in violation of the DRCAFTA's national treatment provision. The investors also allege that the failure of regulatory oversight violated the treaty's fair and equitable treatment and full protection and security provisions.

In this case, there is no contractual relationship between the foreign investors and their host state. The investment itself does not impact the provision of essential public services. Nor is there any concern that this claim or others like it might exceed the vast financial resources of the United

\footnotetext{
${ }^{16}$ Guatemalan, Costa Rican and Dominican Victims of the Stanford Ponzi Scheme and the Government of the United States of America, Notice of Intent to Submit a Claim to Arbitration Under Section B of Chapter 10 of the Dominican Republic-Central America-United States Free Trade Agreement (29 December 2012), available by subscription on Transnational Dispute Management, at: http://www.transnational-dispute-management.com/legaland-regulatory-detail.asp?key=9265.

${ }^{17}$ The Notice of Intent alleges that the SEC Examination staff extensively investigated the Ponzi scheme on at least four separate occasions over a period of 12 years. Each time, it recommended to the SEC Enforcement division that a prosecution be opened, but each time, the SEC Enforcement division declined to take any action. Nor did it publicize any of the Examination staff's findings.
} 
States government. ${ }^{18}$ Still, numerous difficult questions arise that were entirely absent from the Malaysian Historical Salvors and Suez et al disputes.

To begin with, does the DR-CAFTA impose upon its contracting states a positive duty to regulate at some minimally acceptable level? Does it make the contracting states financially liable to foreign investors for governmental regulatory omissions and failures? If so, under what circumstances and with what exceptions? Is it relevant, for purposes of the claimants' national treatment claims, whether a theoretical US investor in the Stanford Ponzi Scheme could somehow obtain compensation for the Texas SEC's oversight failures? ${ }^{19}$ Should it matter (perhaps under a most-favored nation analysis) whether other foreign investors who are not citizens of DR-CAFTA countries could obtain such compensation?

With respect to the claimants' 'fair and equitable treatment' and 'full protection and security' claims, the DR-CAFTA text specifically limits the contracting states' obligations under these provisions of the treaty to the customary international law minimum standard of treatment. The tribunal's interpretation of the scope of the United States' obligations under these provisions therefore matters not only to the Stanford Ponzi Scheme investors and to the United States as respondent, but also to all other DR-CAFTA states in particular, all other states who are subjects of these customary international law rules in general, ${ }^{20}$ and all investors who may invest in any country that similarly allows investors to directly enforce states' customary international law obligations under any investment treaty. ${ }^{21}$

Given the greatly expanded audience of potentially interested parties, it would seem pertinent to think through how the dispute might potentially impact upon the rights and duties of the many other investors and states not before the tribunal. It is of course trite to observe that an arbitral tribunal's decision cannot and does not formally bind anyone other than the disputing parties themselves. No one seriously disputes this position. But by the same token, it is equally

\footnotetext{
${ }^{18}$ At least not for the moment. The claim described here alleges losses of $\$ 2,264,369$ (see ibid. at para 40 ). This is not a large sum by US standards. Should the claim succeed, however, it is possible to envisage many other claims being brought by foreign investors who lost money on the US markets due to the myriad regulatory failures of the US government in the lead-up to the recent financial crisis. In the aggregate, the amounts could be substantial.

${ }^{19}$ Note that the US Trade Act of 2002 (19 US Code $\S \S 3801-3813$ ) constrains the US executive branch from entering into any treaty which treats non-US persons better than US citizens in investment matters. Section 3802(b)(3) of that Act ('Foreign Investment') states:

'... the principal negotiating objectives of the United States regarding foreign investment are to reduce or eliminate artificial or trade-distorting barriers to foreign investment, while ensuring that foreign investors in the United States are not accorded greater substantive rights with respect to investment protections than United States investors in the United States, and to secure for investors important rights comparable to those that would be available under United States legal principles and practice...'

${ }^{20}$ This is to say all states except those few that have conscientiously exempted themselves from these customary international law rules by means of the persistent objector doctrine.

${ }^{21}$ I take no position here on the viability of the claims alleged by the Stanford Ponzi Scheme victims. On the one hand, holding a state financially liable for losses suffered by financial market investors on the grounds of the state's insufficient regulatory oversight would seem to constitute a rather novel expansion of state liability theory on the international plane. On the other hand, it is true that article 2 of the International Law Commission's Draft Articles on the Responsibility of States for Internationally Wrongful Acts (2001) specifically contemplates the possibility that a state's omissions may give rise to its international responsibility. Within the international investment law context, meanwhile, the arbitral jurisprudence on the fair and equitable treatment standard is notoriously muddled.
} 
undeniable that the investor-state jurisprudence is dominated by the practice of citing to, following, and occasionally distinguishing prior arbitral awards. ${ }^{22}$ To deny the power of investor-state awards to shape the future behavior of other states, investors, and arbitral tribunals is to commit the offense we are now told no ostrich has ever actually committed - the proverbial burying of one's head in the sand. Some account must be taken of the realities of arbitral practice.

Summing up, the main point to be gleaned from the Malaysian Historical Salvors, Suez et al, and Stanford Ponzi Scheme illustrations is not simply that the legal and factual parameters underlying the three claims are different. Rather, it is that the parameters differ in systematic ways that are material to any plausible assessment of the three disputes and the manner in which they ought to be resolved. What is needed, therefore, is a systematic way of identifying which cases are like and which are different - and for what purposes.

In what follows, I aim to construct a matrix of factors that point to different considerations, and hence differentiated dispute resolution methodologies, for different types of investor-state disputes. I contend that this type of schematization exercise will prove useful both within the realm of dispute resolution and beyond. It sheds light on questions of interpretation but also of substantive law drafting, and it holds important lessons for overall regime design as well.

\section{The three-dimensionality of investor-state disputes}

Turning now to the brass tacks, how might the differing characteristics of investment disputes be better understood and appreciated in future? I propose that there are three central continuums along which the basic parameters of most investment disputes can be charted: the socio-legal, the territorial, and the political. Figuring out where along these three continuums the various attributes of a particular dispute fall can help draw attention to the special considerations one might wish to take into account in resolving that dispute. I proceed by explaining the motivating idea behind each continuum, highlighting the genre of information each attempts to capture, and suggesting some rough plotting criteria that might be applied when plumbing the contours of concrete investor-state disputes. I then illustrate how my proposed differentiation methodology might work in practice by applying it to three well-known disputes.

\section{A. The socio-legal continuum (individual to societal)}

The idea behind the socio-legal continuum is to situate each particular investor-state dispute within the broader context of the social and legal environment in which it arises. This continuum aims to encapsulate two basic types of information.

- First, how large is the claimant pool relative to the total number of actors who were in some way impacted, whether positively or negatively, by the underlying governmental action which forms the basis of the complaint? ${ }^{23}$

\footnotetext{
${ }^{22}$ See e.g. the discussion in Austrian Airlines v. the Slovak Republic, UNCITRAL, Final Award (9 October 2009), redacted version, paras 83-84 (asserting that tribunals have a duty to adhere to an arbitral jurisprudence constante unless there is good reason to depart from it in a specific case).

${ }^{23}$ Concretely, some illustrative questions might include:
} 
- Second, to what degree do all of the affected actors enjoy the equal ability to safeguard their various rights through access to effective legal remedies? ${ }^{24}$

These questions may appear rudimentary at first blush. Yet they play an important role in determining who pays attention to specific investor-state disputes and how those disputes are perceived by those who do pay attention.

A claim filed by a single claimant - all else being equal - will generally attract less notice than one filed by thousands. ${ }^{25}$ Similarly, if the government conduct giving rise to the claim affects no one but the claimants themselves (as was the case in Malaysian Historical Salvors), then other actors are far less likely to concern themselves with how the dispute unfolds. ${ }^{26}$ By contrast, where a governmental measure impacts upon both claimants and non-claimants and there are notable discrepancies in the legal protections or remedies afforded to the two groups (as was arguably the case in Suez et al), the likelihood of not only broader attention but also social opposition to the arbitration rises. ${ }^{27}$ These considerations make it prudent to pay attention to fundamental social and legal dynamics from the outset of each investor-state claim.

\section{B. The territorial continuum (local to transnational)}

Shifting to the territorial continuum introduces a second set of considerations. The major objective of this continuum is to illuminate the geographical breadth of the dispute - as defined by the dispute's actual and potential impact rather than by the respondent state's formal jurisdictional competence under traditional international law principles. Here again, there are two relevant lines of inquiry.

(1) How many separate (aka legally unaffiliated) claimants are involved in this case?

(2) Not counting the claimants, how many other foreign or domestic persons, whether natural or juridical, also suffered or might plausibly claim to have suffered a direct negative impact (harm) as a result of the government measure(s) that form the basis of this complaint?

(3) Not counting the respondent state's government itself, how many other foreign or domestic persons, whether natural or juridical, received or might plausibly claim to have received a direct positive benefit as a result of the government measure(s) that form the basis of this complaint?

${ }^{24}$ By effective legal remedy, I do not mean to suggest that all of the affected actors must be able to adjudicate their claims before an investor-state arbitral tribunal alongside the investor-claimants. Only that all must have access to some kind of effective forum for the protection of their rights, and their ability to safeguard their rights through that forum must not depend upon the outcome of some other forum to which they do not have a right of access (e.g. an investor-state arbitral tribunal). To get at the essence of this inquiry, one might wish to estimate:

(4) Among all other directly negatively impacted persons who are not claimants in this case (' $\mathrm{N}$ ' from question 2), what percentage has access to a similarly effective adjudicative forum, whether international or domestic, before which they could potentially lodge the same or similar claims against the government measure(s) that form the basis of this complaint?

(5) Among all other directly positively impacted persons, both foreign and domestic (' $\mathrm{P}$ ' from question 4), what percentage might plausibly be considered to have their interests effectively represented by the respondent government in this case?

${ }^{25}$ Of course, all else is never equal. But the point here is not to identify each of the potentially differing features of investor-state disputes, but rather those which are likely to give rise to the need for differentiated dispute resolution methodologies. It is my contention that the number of claimants is one such relevant feature (among others).

${ }^{26}$ Even if the number of claimants is large (again, all else being equal).

27 Anecdotal evidence of this may be seen in the level of media coverage received by certain disputes relative to others, as well as in the intensity of the civil society response provoked. 
- First, what is the territorial scope of the various positive and negative impacts of the maligned governmental action that forms the basis of the complaint?

- Second, how broad is the reach of the major legal claims and defenses that are likely to be argued, in terms of their generalizability to actors outside the territorial borders of the respondent state?

Actual investor-state dispute fact patterns call for myriad different answers to these questions. A blanket government measure that imposes tighter gaseous emissions standards on factories may negatively impact the profitability of all factories located within the host state. If there is only one factory in the country, the negative impact will be highly localized; if there are many, it may be quite diffuse. On the other side of the balance sheet, since gaseous emissions cross borders and affect the entire globe, the new regulation may positively impact all human, animal, and plant life and health not only locally or within the host state but worldwide. This illustrates the relevance of the factual territorial impact of the government's challenged measure.

With respect to the legal territorial scope of the dispute, suppose a foreign factory owner files for arbitration against its host state, claiming compensation for the reduction in profits suffered due to the hypothetical emissions standard just posited. If the claim is based on a stabilization clause in a specific contract, ${ }^{28}$ then the tribunal's interpretation of the various legal claims and defenses should not, in theory, affect the legal rights or obligations of anyone not party to the contract. ${ }^{29}$ But what if the investor claims that the environmental regulation violates the customary international law standard of fair and equitable treatment as contained in the DR-CAFTA, discussed above? In such a case, the arbitral tribunal's resolution of the disputing parties' legal claims and defenses takes on greater import. Although it formally binds only the specific investor and the host state, the tribunal's decision carries the potential to alter the way in which other states and other foreign investors conceive of their similar or identical legal rights and obligations in future regulatory spats. ${ }^{30}$ The extraterritorial legal salience of specific investorstate disputes must therefore also factor into any discussion of appropriate methods for resolving such disputes.

C. The political continuum (commonplace to contested)

\footnotetext{
${ }^{28}$ A stabilization clause is a contractual provision by which a state promises not to alter the regulatory environment in which the investment operates to the detriment of the profitability of the investment, usually over a defined period of time (often 30 years).

${ }^{29}$ This is not to suggest that stabilization clauses in investor-state contracts are a good idea. My own view is quite to the contrary. It is difficult to conceive of many situations in which it would practicable, let alone wise, for a government to prospectively hobble its own ability to respond in a responsible manner to changing economic, social, political, or environmental circumstances with appropriate, public-regarding regulation. For critiques of stabilization clauses, see John Ruggie, International Finance Corporation, 'Stabilization Clauses and Human Rights' (May 2008), at: http://www.ifc.org/ifcext/media.nsf/Content/Stabilization_Clauses_Human_Rights; Robert Howse, 'Freezing Government Policy: Stabilization Clauses in Investment Contracts', 3(1) Investment Treaty News (April 2011), at: http://www.iisd.org/pdf/2011/iisd_itn_april_2011_en.pdf.

${ }^{30}$ Both under the DR-CAFTA and under customary international law, since the former purports to encapsulate the latter.
} 
The final continuum that helps point to different dispute resolution considerations for different types of investor-state disputes is the political continuum. The overriding purpose of the mapping exercise along this continuum is to convey a sense of the degree to which the basic features of the dispute itself and the circumstances in which it arises are likely to be viewed as mundane, ordinary, or commonplace - as opposed to radical, surprising, or contested - by constituencies who may have or perceive themselves as having an interest in the resolution of the dispute. This use of the term 'political' is admittedly somewhat imprecise. That which is considered political will necessarily vary across time, across countries, and across individuals and groups within countries.

Even so, accepting some definitional flexibility may prove useful insofar as it aids the investment law community in identifying which investor-state disputes, and which aspects of particular disputes, stand out as potential flashpoints. I submit that there are several key variables to be noted in this regard, which can be fleshed out by means of the following four questions:

- What is the type and sector of the investment in question?

- How novel or audacious are the investor's claims?

- What is the potential individual and aggregate budgetary impact of contemporaneous investor-state claims upon the host government's fisc?

- What is the economic and political context in which the events giving rise to the dispute took place?

Taking these in order, the investment sector matters because certain types of business activities are almost always more politicized than others. One may think of an investment in the extractive industries in contradistinction to a contract for the construction of a government office building. ${ }^{31}$ As to the audacity of investors' claims, a run-of-the-mill contract claim for nonpayment of services rendered ${ }^{32}$ is a very different beast, politically speaking, from a claim that a vague treaty provision promising 'fair and equitable treatment' entitles an investor to receive compensation for lost profits resulting from the enactment of a new emissions regulation. ${ }^{33}$

Novelty is a related but distinct concept. When investors bring claims of a type that have long found favor with all manner of domestic and international courts and tribunals, ${ }^{34}$ few political eyebrows are raised. By contrast, when an arbitration tribunal ventures into unchartered territory by countenancing a novel claim that goes far beyond the pale of past practice, the tribunal bears an additional burden to justify its unprecedented decision. Otherwise, the decision risks being

\footnotetext{
${ }^{31}$ In a similar comparison-across-industries vein, see the discussion of the Malaysian Historical Salvors and Suez cases, supra, notes 11 to 15 and accompanying text.

${ }^{32}$ Malaysian Historical Salvors, ibid..

${ }^{33}$ See e.g. Methanex Corp. v. United States of America, NAFTA (UNCITRAL rules), Final Award of the Tribunal on Jurisdiction and Merits (3 August 2005), available at http://italaw.com/sites/default/files/casedocuments/ita0529.pdf (rejecting a fair and equitable treatment challenge to an environmental law).

${ }^{34}$ E.g. straightforward breach of contract claims or claims for the outright expropriation or destruction of property.
} 
derided as illegitimate by at least some constituencies - potentially at the cost of the enforceability of the decision.

The proposed budgetary impact consideration may strike many as objectionable at first. After all, why should a state's ability to compensate a foreign investor for a breach of its legal obligations have any bearing upon its duty to pay that investor? Alas, in the real world, government spending is a hotly political issue - and for good reason. A \$300 million award against the United States in 2006 would have been a proverbial drop in that government's fiscal bucket, while the same award against Burkina Faso would have eaten up a third of the government's entire budget for that year. ${ }^{35}$ It seems intuitively obvious that an already cashstrapped government which dutifully cuts back on basic services or raises taxes on its domestic population in order to transfer large amounts of money to foreign investors will not long remain in power. $^{36}$ If this is so, then it is necessary to at least contemplate whether it makes sense to impose, upon the poorer governments participating in the international investment law system, the prospect of occasional forced regime change in consequence of heavy financial liability to foreign investors. ${ }^{37}$

Finally, in respect of economic and political context, a limitless number of variegated factors can raise complex considerations in relation to particular disputes. As a rough sweep, it is useful to simplify things by lumping together into three basic groups the many possible contextual scenarios out of which investor-state disputes may arise: ordinary times, times of economic crisis, and times of political crisis or transition. The latter two are not always mutually exclusive, and each can be further broken down into major and minor crises. But the basic point is that contextual considerations may play a role - sometimes even a decisive one - in determining legal rights and obligations in investor-state disputes. ${ }^{38}$

The Piero Foresti dispute provides an apt illustration of the relevance of this final consideration within the political continuum. ${ }^{39}$ In that case, a group of European investors invested in some South African granite mines in the 1990s, acquiring a set of specified property rights under certain apartheid-era laws then in place. When the new, democratically elected government later amended those laws and enacted a series of Black Economic Empowerment initiatives to redress the previous laws' discriminatory effects, the investors' property rights became less valuable.

\footnotetext{
${ }^{35}$ The World Bank Country Report for Burkina Faso (available at: http://data.worldbank.org/country/burkina-faso) shows general government final consumption expenditures of $\$ 1,268,998,089$ in current 2006 dollars.

${ }^{36}$ Of course, whether or not this would be a good thing may depend on the level of democratic legitimacy enjoyed by the government in question.

${ }^{37}$ It should also be born in mind that such a drastic outcome would undoubtedly reduce the ability of the foreign investors to actually collect on their arbitration awards.

${ }^{38}$ This idea is inherent in the customary international law doctrine of necessity and in contract law doctrines like impossibility, changed circumstances, and force majeure. Contextual considerations are sometimes also explicitly incorporated into bilateral investment treaties. See e.g. article XI of the United States-Argentina BIT, at: http://unctad.org/sections/dite/iia/docs/bits/argentina_us.pdf (allowing deviations from the treaty obligations when necessary to maintain public order, essential security interests, or international peace and security); article 20 of the US Model BIT (2012), at: www.state.gov/documents/organization/188371.pdf (authorizing deviations from treaty obligations related to financial services when undertaken on prudential regulatory grounds).

${ }^{39}$ Piero Foresti and Others v. The Republic of South Africa, ICSID Case No. ARB(AF)/07/01, Award, (4 August 2010).
} 
The investors responded by filing a treaty-based arbitration claim against South Africa. ${ }^{40}$ Needless to say, any legal decision-maker wishing to evaluate the investors' entitlement to compensation in such circumstances would be remiss to ignore the underlying political context. It would be absurd not to consider how the relative legitimacy of an apartheid era versus democratically enacted set of laws might impact upon the legal claims at issue. ${ }^{41}$ Inverse considerations might well apply in cases where a democratic government is instead swept aside by a military coup - as has recently happened in Egypt. ${ }^{42}$ Economic crises, for their part, raise parallel complexities.

The value of the political continuum lies in its ability to put all of these potential political storms on the radar screen of investment lawyers, arbitrators, and treaty negotiators.

\section{Three cases in 3-D}

The previous part sketched out, in rough terms, what it might look like to differentiate between different types of investment disputes along lines that can point the way toward a more nuanced approach to resolving them. In this section, I walk through the exercise of applying my proposed differentiation methodology to three concrete investor-state disputes. All three disputes are wellknown within the investment arbitration community. They were selected, however, not for their fame but for their ability to highlight distinctive aspects of the differentiation methodology and to show how it may be used as a regime-improving mechanism.

In developing each case study, I have asked and answered the basic questions proposed in the preceding part. ${ }^{43}$ Those questions are designed to enable a reasonably knowledgeable lawyer, on the basis of the disputing parties' preliminary written submissions, ${ }^{44}$ to quickly situate a given investor-state dispute along the socio-legal, territorial, and political continuums described above. $^{45}$ A brief perusal of the bulleted questions will reveal that they are blunt, of limited bandwidth, and inevitably rife with potential subjectivity problems. In these respects they are very much like the arbitral decision-making process which they are intended to assist. I have offered them here not as a final solution but as a beginning step on the journey toward a more finely-tuned international investment law system. They are a tow-rope up a steep ski hill in an age when everyone yearns for a heated high-speed gondola. But gondolas take time to build, and if one wishes to ski in the interim, a tow-rope is often better than nothing.

\footnotetext{
${ }^{40}$ They alleged that their property had been directly and indirectly expropriated without compensation, that they had been treated unfairly and inequitably, and that they had been subjected to nationality-based discrimination.

${ }^{41}$ Happily, the arbitrators were spared this task, as the claim was withdrawn before it came up for decision.

${ }^{42}$ This scenario may well arise in the context of investor-state claims against Egypt in the wake of the military's ouster of Egypt's first democratically elected president.

${ }^{43}$ To keep the discussion to a reasonable length, in what follows I highlight only the more striking observations to emerge from the differentiation mapping exercise for each case study.

${ }^{44}$ In most cases, the information sought in the questionnaire will be available on the basis of the Claimant's initial Request For/Notice Of Arbitration, together with the Respondent's initial observations in response to that request or notice.

${ }^{45}$ Using publicly available documents and electronic search functionalities, it took me an average of 20 minutes to fill out the questionnaire for each case. A reader less familiar with the cases might well have taken somewhat longer. However, the odds are good that a reader who (unlike me) had access to the non-redacted initial submissions of the disputing parties would have been able to complete the questionnaires in less time.
} 


\section{A. Asian Agricultural Products Ltd (AAPL) v. Sri Lanka: a path-breaking dispute}

The facts of this case are relatively straightforward. The arbitral tribunal summarized them as follows: ${ }^{46}$

According to the Claimant, the Company's farm, which was its main producing center, was destroyed on January 28, 1987, during a military operation conducted by the security forces of Sri Lanka against installations reported to be used by local rebels. As a direct consequence of said action, AAPL alleged having suffered a total loss of its investment, and claimed from the Government of Sri Lanka compensation for the damages incurred [\$US $8,067,368]^{47}$ as a result thereof.

As is clear from the description, this dispute involved a single claimant. The investment was made in a lightly regulated industry (shrimp farming) which was not known to be politically sensitive in Sri Lanka. The cause of action was a discrete set of events (anti-rebel military operations) that occurred in a specific locale over a short period of time. ${ }^{48}$ The central claim was one of compensation for physical destruction of property - a rather non-controversial type of claim as international law claims go.

It is perhaps unsurprising, on these facts, that the $A A P L$ dispute raises relatively few special considerations of note within the socio-legal and territorial mapping continuums. Indeed, as readers familiar with the history of investment arbitration will know, the most noted aspect of this case is that it was the first publicly reported dispute in which an investor's claims were recognized on the basis of obligations contained in a bilateral investment treaty rather than in a contract $^{49}$ or in a politically negotiated submission agreement. ${ }^{50}$ The most salient feature of the dispute, from an historical perspective, was thus the novelty of its jurisdictional basis.

This being the case, it is interesting to note that the arbitrators in AAPL v. Sri Lanka went out of their way to justify the decision with extensive reasoning. The tribunal devoted more than three full pages to laying out the general interpretive principles to be applied to treaties under international law ${ }^{51}$ before spending six pages applying those principles to the bilateral investment treaty at hand. ${ }^{52}$ It next took two pages to summarize the accepted international law rules on the evaluation of evidence in international disputes, ${ }^{53}$ and then described, over the course of five pages, how it would proceed to apply those rules in the case before it. ${ }^{54}$ All of this occurred

\footnotetext{
${ }^{46}$ Asian Agricultural Products Ltd (AAPL) v. Republic of Sri Lanka, ICSID Case No. ARB/87/3, Final Award (27 June 1990), 30 InT’L LEGAL MATERIALS 580 (1991) [hereinafter AAPL - Award], p 581.

${ }^{47}$ Ibid. at p. 584, para 9 (in quoted para 2).

${ }^{48}$ Of course, the events were part of a larger and longer-term military campaign against the alleged rebels - a fact which seems to have factored into the tribunal's compensation assessment, as I note below.

${ }^{49}$ As had been the case in all ICSID registered disputes up to that date.

${ }^{50}$ Such as those underpinning claims before the early $20^{\text {th }}$ century 'Mixed Claims Commissions' and the Iran-US Claims Tribunal.

${ }^{51}$ AAPL - Award, supra note 46, pp. 594-597 (developing what it termed Rules A through F of international legal interpretation).

${ }^{52}$ Ibid. at pp. 597-603.

${ }^{53}$ Ibid. at pp. 603-604 (positing its Rules G through M on evidentiary evaluation).

${ }^{54}$ Ibid. at pp. 604-609.
} 
before the tribunal even reached the part of its award titled 'The Legal and Factual Considerations on which the Respondent's Responsibility is Established'. 55

Even outside of these passages, it is striking, when reading the award, how many times the tribunal refers to international law sources beyond the investment treaty itself, including: other treaties and conventions, the decisions of other international courts and tribunals (in both investment-related and non-related cases), the writings of prominent international law scholars, and the principles contained in soft law instruments promulgated by venerable international institutions such as the International Law Commission. The award is littered with dozens of such references. What this suggests is that the members of the AAPL tribunal were well aware of the fact that they were rendering a rather novel decision within the international investment law domain. $^{56}$

This part of the tribunal's dispute resolution strategy appears to have been well-calculated in retrospect. At the time the award came out, it by no means flew under the radar screen. Prominent scholars quickly recognized what a tectonic shift of the international investment regime's plates it signaled, ${ }^{57}$ yet few seriously challenged the correctness of the decision's jurisdictional holding. ${ }^{58}$ The phenomenon of treaty-based investment disputes took off rapidly as a result. Today, large numbers of investor-state claims are based on treaties. ${ }^{59}$ Legal justification, it seems, eventually begat sociological acceptance in this regard. ${ }^{60}$

But there is another facet to the story worth noting here - one that is often overlooked in contemporary references to the $A A P L$ case - and this relates to the political continuum. Recall that the investor's claim stemmed from a military operation undertaken in order to put down a 'major insurrection launched by well-armed insurgents engaged in a sophisticated guerillawarfare against Government forces. ${ }^{61}$ In addition to destroying the claimant's shrimp farm, this counterinsurgency operation damaged a number of other surrounding properties and claimed the lives of thirteen members of the government security forces, ${ }^{62}$ fifteen alleged insurgents, and five civilians. ${ }^{63}$ The government's actions thus imposed severe and highly concentrated costs upon

\footnotetext{
${ }^{55}$ Ibid., bottom of p. 609.

${ }^{56}$ It is probably for this reason that they took such great pains to ensure that the decision would enjoy a high degree of what Richard Fallon called 'legal legitimacy' - the sense that the decision has come into being through proper and generally accepted interpretive processes. See Richard Fallon, 'Legitimacy and the Constitution', 118 Harvard Law Review (2005) 1787.

${ }^{57}$ For a discussion of the award's reception, see Jan Paulsson, 'Arbitration Without Privity', ICSID Review Foreign Investment Law Journal (1995) 232.

${ }^{58}$ Not even the many states who were later surprised to realize that their governments had agreed to accept direct treaty-based arbitration with investors under dozens of hastily signed investment treaties.

${ }^{59}$ The precise ratio is unknown, since contract-based disputes are often not made public. Since $A A P L$, however, at least 450 treaty-based cases have been brought. UNCTAD IIA Issues Note No. 1 (2012), at: http://unctad.org/en/pages/newsdetails.aspx? OriginalVersionID $=64$.

${ }^{60}$ Moral legitimation, of course, is a different question. There are now quite a few voices calling for the denunciation of investment treaties, or at least their investor-state arbitration provisions. But these calls do not stem from a belief that the $A A P L$ case was incorrectly decided. Rather, they are motivated by legitimacy concerns having to do with the scope and breadth of the substantive obligations found in contemporary investment treaties.

${ }^{61}$ Asian Agricultural Products Ltd (AAPL) v. Republic of Sri Lanka, ICSID Case No. ARB/87/3, Dissenting Opinion of Samuel K.B. Asante (27 June 1990), 30 ILM (1991) 628 [hereinafter AAPL - Dissent], at p. 651, para 3.

${ }^{62}$ Ibid.. at p. 651, para 4.

${ }^{63}$ Ibid. at p. 629, para 6.
} 
the few in the quest for significant and widespread benefits (in the form of improved security) for the many. The surrounding circumstances, in short, were deeply political.

This explains why one arbitrator saw fit to append a passionate dissent in which he objected to the majority's finding of liability against the state. ${ }^{64}$ More subtly, though, it may also explain the majority's otherwise difficult-to-comprehend approach to the quantum calculations. ${ }^{65}$ The claimant had requested $\$ 8$ million in compensation on the basis of its share in what it alleged to be the discounted cash flow value of the investment. While this sounds like a modest sum in modern transnational business terms, in the year when the arbitration claim was lodged, eight million dollars would have amounted to a significant portion of the Sri Lankan government's total annual expenditures. ${ }^{66}$ Had the government been obligated - perhaps under other investment treaties or under the equality provision of the Sri Lankan constitution - to similarly compensate all other affected property holders, ${ }^{67}$ it might soon have found itself priced out of its counterinsurgency fight against the Tiger rebels. ${ }^{68}$

The majority of the tribunal made no reference to such considerations in its liability findings, of course. But when it came to the quantum discussion, the majority performed a curiously opaque version of a book asset valuation which resulted in an award of only $\$ 460,000 .{ }^{69}$ It is hard to square this compensation outcome with the logic of the tribunal's liability findings. Yet the Sri Lankan government honored the award without further contestation. One wonders what kind of unacknowledged role the underlying political circumstances might have played in this chain of events.

At this point, one may anticipate a principled objection from the legal purist: is it not antithetical to the rule of law to even countenance the prospect of politically shaped damages awards? Wouldn't this only encourage states to flout their international legal commitments? In a word: no. It has long been recognized that the international law principle of full reparation of damages $^{70}$ assumes a wide variety of guises in practice: discounted cash flow valuations, net book value calculations, replacement cost estimates, the 'actual investment' approach, and others. ${ }^{71}$ What the $A A P L$ case helps to underscore is that different political dimensions often do

\footnotetext{
${ }^{64}$ Ibid. at p. 651 (concluding that the majority opinion 'touches on the sovereign prerogatives of a Government fighting for its very life').

${ }^{65}$ See AAPL - Award, supra note 46, pp. 619-625 (detailing the majority's method for determining quantum). The opacity of the method is curious for its stark contradistinction to the painstaking effort expended by the tribunal in justifying other parts of the award.

66 Around $1.22 \%$. See World Bank Country Report for Sri Lanka (available at: http://data.worldbank.org/country/sri-lanka) showing general government final consumption expenditures of $\$ 663,654,891$ in the year of the claim (1987).

${ }^{67}$ Note that the claimants in the $A A P L$ case owned only $48 \%$ of the shares in the destroyed shrimp farm (AAPL Award, supra note 46, p. 620, para 91). Under the claimant's proposed valuation method, compensating the other $52 \%$ shareholders would have required an additional $\$ 8,739,649$, bringing the total compensation claim for just that one farm to a collective $2.54 \%$ of the government's annual expenditures in the year of the claim.

${ }^{68}$ Especially considering that the military offensive at the heart of this complaint was only one of many carried out over multiples years' worth of battles with the insurgents.

${ }^{69}$ This came to around $0.06 \%$ of the government's expenditures in the year of the award.

${ }^{70}$ A principle generally traced to the Case Concerning the Factory at Chorzów, PCIJ Series A, No. 9 (Judgment of 26 July 1927).

${ }^{71}$ For an overview of how the various methods have been applied in international investment law cases, see Sergei Ripinsky and Kevin Williams, Damages in International Investment Law (2008).
} 
and most likely should give rise to different quantum methodologies in different cases. It is worth pondering whether, as a matter of policy, it would be preferable to pay more explicit attention to how the political features of investor-state disputes are shaping actual compensation outcomes in international investment law. ${ }^{72}$ Analyzing this connection in a transparent fashion could prove to be a useful catalyst in developing clearer guidelines for how tribunals should go about selecting among international law's various available compensation methods in future cases. One might even imagine inserting substantive law provisions along these lines into nextgeneration investment treaties. ${ }^{73}$ It behooves investment lawyers to recognize such political complexities and deal with them head-on where possible.

To summarize, then, the $A A P L$ case shows that investment arbitrators already have a handful of discursive and interpretive tools at their disposal to help meet some of the distinctive challenges posed by novel, sizeable, ${ }^{74}$ and politically charged investment claims. But when and how tribunals choose to deploy these tools remains very much a matter of discretion. Perhaps the principal takeaway of the case study is that the voluntary application of differentiated dispute resolution strategies by tribunals can help increase the prospect that novel investor-state arbitration awards will be enforced, even in difficult economic and political circumstances. This may in turn increase the odds that future tribunals will be willing to follow their bushwhacking predecessors down new jurisprudential paths. On the downside, self-directed strategies can only yield jurisprudence-shaping dividends for investor-state arbitration when actually employed, and even then, only when employed transparently. In some areas - like the determination of which compensation method to apply in which circumstances - it may be impossible for arbitrators to converge upon a consistent yet contextually differentiated set of dispute resolution practices without first receiving clearer guidance from lawmakers ${ }^{75}$ via the applicable substantive law.

\section{B. Abaclat v. Argentina: an extraordinary crisis dispute}

The next two case studies examine disputes that are still in process. This provides the opportunity to reflect upon some of the salient features of investment disputes currently making headlines today. The basic facts of the Abaclat dispute ${ }^{76}$ are as follows.

In December of 2001, in the midst of a massive financial crisis, the government of Argentina defaulted on its sovereign debt 'by publicly announcing the deferral of over US\$100 billion of

\footnotetext{
${ }^{72}$ Susan Franck has noted that claimants almost never receive as much as they request and that compensation awards do not seem to be strongly correlated with a) the development status of the host country or b) the development status of the arbitrators' countries of origin. See Susan Franck, 'Empirically Evaluating Claims About Investment Treaty Arbitration', 86 North Carolina Law Review (2007) 1; Susan Franck, 'The ICSID Effect? Considering Potential Variation in Arbitration Awards', 51(4) Virginia Journal of International Law (2011) 977, at 856. However, to my knowledge, there has not yet been an empirical study attempting to link compensation awards with the factors suggested by my three proposed differentiation continuums. I hope to be able to turn to such empirical work in the future.

${ }^{73}$ This is one of those broader systemic implications I alluded to earlier.

${ }^{74}$ In terms relative to the host state, that is.

${ }^{75}$ By 'lawmakers,' here, I mean treaty negotiators (for treaties), domestic legislatures (for investment statutes), and contracting parties (for investor-state contracts).

${ }^{76}$ Abaclat and Others v. Argentine Republic, ICSID Case No. ARB/07/5, Decision on Jurisdiction and Admissibility (4 August 2011) [hereinafter Abaclat - Award on Jurisdiction].
} 
external bond debt owed to both non-Argentine and Argentine creditors. ${ }^{, 77}$ The subsequent $70 \%$ depreciation of the Argentine peso 'accentuated the weight' of Argentina's foreign currencydenominated debt, which led it to seek a major debt restructuring. ${ }^{78}$ In the ensuing years, Argentina successfully restructured $91.3 \%$ of its debt ${ }^{79}$ through a series of debt swaps in which creditors accepted lower yield, lower value, or longer maturity bonds in exchange for renewed repayment promises. ${ }^{80}$ A number of holdout creditors, however, refused to participate in the debt restructuring and instead turned to various courts and arbitral forums all over the world in an attempt to recover the full value of their original debt holdings. ${ }^{81}$

The Abaclat claimants are one such group of holdout creditors. Their claims, which were brought under the Italy-Argentina bilateral investment treaty, are being pursued by an Italian Association called Task Force Argentina (TFA) on behalf of 60,000 individual foreign holders of defunct Argentine sovereign bonds. The case marks the first ever 'mass arbitration' to proceed under international investment law.

Feeding the parameters of this dispute into the questions suggested above brings to the fore noteworthy characteristics within all three of my proposed differentiation mapping continuums. It is easy to understand why. On the social-legal front, Abaclat involves a huge number of claimants. This means the dispute was bound to attract immediate and sustained media attention. $^{82}$ And yet, sizable though the claimant pool may be, it is clear that it constitutes only a tiny fraction of the total number of people who were affected - both positively and negatively by the government actions forming the basis of the complaint. On the negative impact side, thousands of domestic Argentine bondholders suffered an identical evisceration of the value of their original bonds, as did thousands of foreign bondholders - many of whom cannot claim the protection of any applicable investment treaty. Few of these other affected bondholders enjoy

\footnotetext{
${ }^{77}$ Ibid., at para 58. See also para 63, stating: 'Based on figures produced by Respondent, by the end of 2002 [a year later], Argentina's total public debt burden was approximately US\$ 137 billion, representing approximately $130 \%$ of its GDP in 2002, and among which approximately US\$ 76 billion was owed to resident and nonresident public bondholders.'

${ }^{78}$ Ibid. at para 62.

${ }^{79}$ Report of J.F. Hornbeck, United States Congressional Research Service, 'Argentina's Defaulted Sovereign Debt: Dealing with the "Holdouts" (6 February 2013) [hereinafter 'Hornbeck Report'], p. 8, at: Www.fas.org/sgp/crs/row/R41029.pdf.

${ }^{80}$ Abaclat - Award on Jurisdiction, supra note 76, at paras 71-81.

${ }^{81}$ Ibid., at para 82, noting that the announcement of Argentina's 2005 restructuring offer was followed by hundreds of lawsuits, including:

i) '[o]ver 130 lawsuits brought in the US... seeking repayment of approximately US\$ 3.3 billion in principal and accrued interest...',

ii) '470 court proceedings filed against Argentina in Germany, with claims amounting to a total of approximately EUR 106 million...', and

iii) '[t]hirteen lawsuits filed against Argentina in Italy before civil courts, with claims amounting to a total of approximately EUR 71 million'.

${ }^{82}$ In the political science literature, empiricists often use the frequency of media reporting as a measure of the politicization of international issues. See e.g. Thomas Rixen and Bernhard Zangl, 'The Politicization of International Economic Institutions in US Public Debates', 8 Review of International Organizations (2013) 363.
} 
the ability to bring the sorts of claims lodged by the Abaclat claimants before an effective alternate forum. ${ }^{83}$

As to the positive impacts of the government's actions, thousands of restructured bondholders, both foreign and domestic, have benefitted from the government's resumption of its debt service obligations, albeit at a sharply reduced rate. This is a net gain over the prospect of receiving no repayment at all, which would have been the likely outcome had all of the bondholders held out for full repayment as the Abaclat claimants have done. These facts raise important legal questions concerning the safeguarding of widely shared norms like equality, non-discrimination, and access to justice. They also beg moral questions in relation to certain felt social norms, such as the notion that crisis situations should be met with some level of solidarity and burden sharing.

Moving on to the territorial continuum, for a claim challenging the actions of a single sovereign, the Abaclat case is a remarkably transnational affair. The sovereign bonds held by the claimants were purchased not on domestic but on international capital markets. There is nothing in the facts to suggest that any of the 60,000 claimants ever even set foot in Argentina. ${ }^{84}$ The same goes for a large proportion of all other purchasers of Argentine sovereign debt in the period 1991-2001, the vast majority of which was sold to non-Argentine buyers via international markets. ${ }^{85}$ The bulk of the negative impact of Argentina's actions (the financial 'haircut' imposed by the debt restructuring) thus fell on persons outside of Argentina. By the same token,

\footnotetext{
${ }^{83}$ Restructured bondholders had to give up all legal claims arising out of their original bond holdings as a condition of participating in the restructuring deal. Among holdout bondholders, domestic law prevents such claims from being lodged in the Argentine courts, which means Argentine citizens do not have access to an effective forum. As to foreign holdout creditors, sovereign immunity doctrines typically stymie the effective resolution of such suits before the courts of other countries. Even where claimants succeed in obtaining a foreign court judgment against a defaulting sovereign, domestic and international legal prohibitions on the attachment of sovereign assets often render it impossible to collect on the judgment. For a consideration of the reasons behind these policies and the attempts by one US corporation to circumvent them in the US courts, see Mark Weidemaier, 'Sovereign Debt After NML v. Argentina', Capital Markets Law Journal (forthcoming), at: http://papers.ssrn.com/sol3/papers.cfm?abstract_id=2199655 (discussing the implications of NML Capital Ltd. v. Republic of Argentina (2d Cir. Oct. 26, 2012) (Nos. 12-105(L) etc.). See also Arrêt n 867 du 28 septembre 2011 (09-72.057) - Cour de cassation (France) - Première chambre civile, La société NML Capital Ltd (Demandeur) et La République Argentine (Défendeur), at: http://www.courdecassation.fr/jurisprudence_2/premiere_chambre_civile_568/867_28_21103.html\# (rejecting, on sovereign immunity grounds, NML's attempt to attach Argentine assets in France).

${ }^{84}$ This fact, in conjunction with the wording of article 2 of the Argentina-Italy Bilateral Investment Treaty (stating that the BIT protects investments in the territory of the host state) led one arbitrator to dissent from the majority's finding that the investment arbitration tribunal has jurisdiction to hear the case. See Abaclat and Others $v$. Argentine Republic, ICSID Case No. ARB/07/5, Dissenting Opinion of Georges Abi-Saab (on the Tribunal's Decision on Jurisdiction and Admissibility) (28 October 2011), paras 73-119.

${ }^{85}$ Abaclat - Award on Jurisdiction, supra note 76, para 50, stating, in relevant part:

'In total, from 1991 through 2001, Argentina placed over US\$ 186.7 billion in sovereign bonds across both domestic and international capital markets. This included 179 bonds issued in the international capital markets that raised a total of approximately US\$ 139.4 billion... . Out of the 179 bonds issued by Argentina, 173 were denominated in foreign currencies; six were denominated in Argentine Pesos. Claimants allegedly purchased 83 of the 173 foreign currency bonds.' (Internal citations omitted.)
} 
one of the chief positive benefits of the restructuring (the resumption of debt service where there otherwise might have been none) also accrued principally to persons outside of Argentina. ${ }^{86}$

The claims and defenses being pled in the case likewise portend a rather broad territorial reach. Never, before Abaclat, had a sovereign default been the subject of an investment treaty claim. Nor had any prior tribunal ever countenanced a mass treaty claim against a state. As a result, the decision by the Abaclat majority to accept jurisdiction over these claims constitutes a doublewhammy on the novelty front. No doubt this is why the tribunal, in its attempt to navigate these uncharted waters, is busy producing a record number of procedural orders and, in another new twist, dissents to procedural orders - each one supported by lengthy reasoning. ${ }^{87}$

From a territorial perspective, Argentina is not the only country with an interest in the manner in which the Abaclat tribunal wends its way through this terra nova. The investors' claims, novel though they may be, rest on legal provisions common to most of the international investment treaties currently in existence. ${ }^{88}$ Similarly, Argentina's defenses rest on broadly replicated investment treaty provisions, along with the even more broadly applicable customary international law defense of necessity. Nor is Argentina the only country bound by international investment obligations that ever has, or ever will, experience a sovereign debt crisis. The claims, defenses, and circumstances are all generalizable, in other words. This means the Abaclat tribunal's administration and resolution of the case will have reverberations beyond the parties in dispute, even if its award binds only those parties on a formal level. Extraterritorial reverberations are already evident in the claims now beginning to trickle in against Greece and Cyprus in the wake of their own debt crises. ${ }^{89}$

Turning then to the political continuum, a notable feature of many of the Argentine crisis disputes is the impressive sums involved, both in the individual and in the aggregate. The precise amount claimed by the Abaclat investors does not yet appear to be a matter of public record. However, stitching together various bits of information from the tribunal's jurisdictional award yields an estimated compensation claim of around $\$ 1.6$ billion. ${ }^{90}$ This was the equivalent

\footnotetext{
86 Argentina's 2005 and 2010 debt restructurings were nevertheless conspicuously territorial in one respect. In contrast to nearly every other sovereign debt restructuring since World War II, Argentina determined the terms of its 2005 and 2010 restructuring offers on a unilateral basis rather than in conjunction with the usual international participants in such deals, namely the IMF, the World Bank, and the Paris Club of Creditors. It remains unclear who bears the greater share of the blame for Argentina's decision to move forward without the consent of these important players. But what does seem clear is that the unilateral nature of Argentina's debt restructurings has emboldened the holdout creditors to reject them all the more vociferously and is contributing to the increasing diplomatic ostracization of Argentina within the community of states. See Hornbeck Report, supra note 79, pp. 9-12.

${ }^{87}$ So far, twenty orders and counting. Details and downloads of the procedural orders and dissents may be found by searching under the case name on the ICSID website: https://icsid.worldbank.org/ICSID/FrontServlet.

${ }^{88}$ The claims arise under standard treaty provisions on expropriation, fair and equitable treatment, full protection and security, etc.

${ }^{89}$ See 'Cyprus and Greece crisis claims', 6(7) Investment Arbitration Reporter (3 April 2013), at items 1 and 2. For an evaluation of the prospective claimants' prospects of success against Greece, see Ioannis Glinavos, 'Investors vs. Greece: The Greek 'Haircut' and Investor Arbitration Under BITs', Working Paper (15 May 2012), at: http://papers.ssrn.com/sol3/papers.cfm?abstract_id=2021137.

${ }^{90}$ Abaclat - Award on Jurisdiction, supra note 76, para 68 states that '[a]llegedly, over 450,000 Italian persons and entities claimed to have held Argentine bonds for an aggregated nominal amount of US\$ 12 billion and submitted their mandates to TFA'. If we assume that the claimants are seeking recovery of the full value of the bonds, and that the value of the bonds held by the 60,000 remaining claimants is proportional to the total value of the bonds
} 
of six percent of Argentina's total government expenditures for the year in which the claim was lodged. $^{91}$ On an aggregate basis, if Argentina were to be found liable to pay this amount not only to the Abaclat claimants but to all other private sector holdout bondholders on an equal basis, ${ }^{92}$ the ratio would rise to over $42 \%$ of annual government expenditures. ${ }^{93}$ These weighty figures emerge even before taking account of the large sums claimed by foreign investors in the 40 other known investment arbitrations to arise out of Argentina's 2001-2002 financial crisis. They also leave aside the 6.3 billion in debt Argentina owed (and still owes) to countries within the Paris Club of creditors. ${ }^{94}$

The point here is not to argue that the Abaclat investors' claims lack legal merit or that Argentina should be absolved of all international responsibility for its actions. Altogether ignoring the harms done to foreign and domestic investors by Argentina would surely not constitute a just response to the series of events that have unfolded. But the facts of the situation in its totality are such that one conclusion is nevertheless inevitable: Argentina cannot plausibly pay back every foreign investor who lost money as a result of its most recent financial crisis. Even if it were within the realm of financial possibility to do so, ${ }^{95}$ it will never be within the realm of political possibility. Not when the crisis imposed such heavy costs on the domestic population as well. ${ }^{96}$ Further compounding the political contestability of the dispute is the fact that the claimants here chose to make a direct investment in the government fisc - an investment known to be highly risky and politically sensitive in a country like Argentina, with its volatile economic and political history.

If it is to have any hope of rendering an enforceable award, therefore, the Abaclat tribunal will have to find some way of tipping its hat to these economic and political realities when interpreting and applying the provisions of the relevant treaty. ${ }^{97}$ Perhaps the tribunal will follow in the AAPL majority's footsteps by reducing the eventual compensation awarded in some opaque manner. Or perhaps, as some have urged, it will put a new twist on the investment law concept of 'legitimate expectations' by finding that the Abaclat claimants could not have

allegedly held by the 450,000 initial prospective claimants, then the nominal value of the remaining claims still being asserted before the ICSID tribunal should come to around $\$ 1.6$ billion.

${ }^{91}$ The World Bank Country Report for Argentina (available at: http://data.worldbank.org/country/argentina) shows general government final consumption expenditures of \$26,575,978,580 in current 2006 dollars.

${ }_{92}$ Again, under general principles like non-discrimination and equal protection.

${ }^{93}$ See Hornbeck Report, supra note 79 at p.7 (noting that $\$ 11.2$ billion in private sector holdout debt remained after Argentina's 2010 exchange offer, not counting \$6.3 billion in outstanding debt to Paris Club creditors).

${ }^{94}$ Ibid..

${ }^{95}$ As some commentators suggested it might have been a couple of years ago. At the time of this writing, however, accusations by the IMF that Argentina has been reporting false growth and inflation information makes the possibility that Argentina might fully repay its defaulted bondholders seem more remote than ever. See 'Statement by the IMF Executive Board on Argentina', Press Release No 13/33 (1 February 2013) at: http://www.imf.org/external/np/sec/pr/2013/pr1333.htm.

${ }^{96}$ Note, too, that the gravity of Argentina's economic and social crisis was more severe and widespread than the Sri Lankan security crisis at the heart of the $A A P L$ case discussed above, so the political legitimacy considerations discussed in that case apply with even greater force here.

${ }^{97}$ There is ample room for such interpretive flexibility, since the Italy-Argentina BIT hails from the 1980s-1990s era of broad and vaguely worded investment treaties. 
legitimately expected full repayment from a government with a long history of financial profligacy and sovereign default. ${ }^{98}$

Whatever the eventual outcome, I have doubts as to whether any tribunal can be expected to clear so many high socio-legal, territorial, and political hurdles using self-selected interpretive strategies. Clearly, the Abaclat tribunal must do its best if it wishes to produce an enforceable award. But the major lesson that the present differentiation mapping exercise generates is that tribunal-directed efforts alone are sometimes not enough. The investment arbitration system's architects and sustainers will have to devote much more serious attention to developing differentiated dispute resolution strategies at the front end if disputes over lightening-rod cases are to be resolved smoothly at the back end through international arbitration proceedings that intentionally eschew international and domestic political processes.

It may be, for example, that sovereign debt defaults are simply too politicized to be arbitrated under investment treaties. If so, states should make clear that their investment treaties do not apply to sovereign debt disputes. ${ }^{99}$ Alternatively, or additionally, one could imagine an investment treaty provision which precisely defines what counts as 'legitimate expectations' and the level at which the treaty entitles investors to be compensated in consequence of a state's contravention of those expectations. ${ }^{100}$ Overall, some combination of tribunal-led and substantive law reform strategies will be needed in order to respond to the economic and political complexities inherent in sovereign debt defaults.

The same is likely true of mass investor-state disputes more generally and of parallel disputes arising out of the same set of facts or circumstances. Other commentators have noted that adopting mandatory institutional rules or voluntary best practices on consolidation and joinder could help to reduce the inconsistency problems associated with multiple and conflicting

\footnotetext{
${ }^{98}$ This move would of course prove unpopular with those members of the investment arbitration bar who believe that the function of legitimate expectations doctrine is only to strengthen, and never to weaken, foreign investors' claims to compensation in respect of profit-reducing governmental acts. Nevertheless, critics of the regime have sometimes argued - not unreasonably - that the word 'legitimate' must place real constraints on the ability of investors to recover compensation for their disappointed expectations. See e.g. Amicus Curiae Submission in Suez, Sociedad General de Aguas de Barcelona, S.A. and Vivendi Universal, S.A. v The Republic of Argentina, ICSID case No. ARB/03/19, pp. 18-21 (arguing that since no government may contract around its human rights obligations, investors cannot legitimately expect a government to violate its human rights obligations to its citizens in order to uphold its financial obligations toward foreign investors in situations where the two come into conflict).

${ }^{99}$ For a discussion of some US treaties that except sovereign debt, and the pros and cons of the US negotiating strategy in respect of sovereign debt overall, see Kevin Gallagher, 'The New Vulture Culture: Sovereign Debt Restructuring and Trade and Investment Treaties', IDEAS Working Paper Series, No. 02/2011, pp. 21-25, at: www.ase.tufts.edu/gdae/publications/GallagherSovereignDebt.pdf. See also UNCTAD, 'Sovereign Debt Restructuring and International Investment Agreements', IIA Issues Note No. 2 (July 2011), at: www.unctad.org/en/Docs/webdiaepcb2011d3_en.pdf.

${ }^{100}$ Such a provision might make a finding of the legitimacy of the investor's treaty-based expectations a function of the ex ante foreseeability of the maligned governmental measure and might prescribe a specific compensation method that takes into account the availability, at the time of the investment, of alternative risk-reduction mechanisms (such as political risk insurance or the ability to obtain a specific contractual commitment from the host state) and the comparative compensability of similar violations of investor expectations within other wellfunctioning legal systems (perhaps along the lines of the comparative public law analysis suggested by Montt and Schill, supra note 3).
} 
arbitration decisions on similar points of law. ${ }^{101}$ In my view, procedural innovations could indeed constitute a step in the right direction. They might reduce the incidence of inconsistent outcomes, which could in turn help combat criticisms that investment arbitration lacks basic legal legitimacy. Such procedural fixes would not, however, necessarily lead to broader public acceptance of investment arbitration as a means for resolving such disputes. Much would depend upon the particulars of the newly consistent direction taken by tribunals. I suspect a final resolution of this controversy will prove elusive unless and until investment treaty texts begin to dictate how investment arbitration tribunals should go about resolving disputes that arise out of widespread political, economic, or social crisis situations affecting numerous constituencies. Next-generation treaty provisions must address the problem of broader context if they are to empower arbitrators to reach not only consistent but also politically and socially palatable (and therefore enforceable) awards.

\section{Philip Morris Asia v. Australia: an ordinary regulatory dispute}

The third and final case study, Philip Morris Asia v. Australia (Philip Morris), ${ }^{102}$ is an exemplar of the 'regulatory disputes' category of cases mentioned above. It highlights yet another distinctive set of the many differentiated considerations that can arise within the realm of investor-state arbitration. Here the primary challenge lies not in equipping arbitrators to adjudge mass claims or claims arising out of extraordinary crisis situations, but rather in figuring out whether and how arbitrators should assess ordinary governmental regulatory activities under investment treaties. I have elsewhere described the basic facts of the Philip Morris case as follows:

In November of 2011, the Australian parliament approved the Tobacco Plain Packaging Act (TPP Act). The Act attempts to 'reduc[e] the attractiveness and appeal of tobacco products to consumers' by 'prohibit[ing] the use of trade marks, symbols, graphics or images on or in relation to tobacco products and packaging.' Philip Morris responded to the new Australian legislation by filing an investment treaty claim against Australia through its subsidiary, Philip Morris Asia Limited, a Hong Kong company. It brought the claim under the bilateral investment treaty (BIT) between Australia and Hong Kong.

In its notice of arbitration, Philip Morris has alleged that Australia's prohibition on the display of tobacco-related trademarks has expropriated the value of its shares by 'destroy[ing] the commercial value of the [company's] intellectual property and goodwill' and 'undermin[ing] the economic rationale of the investments'. It further claims that the Act violates the treaty's fair and equitable treatment guarantee by frustrating the company's legitimate interests and expectations concerning the profitability of its investment. By way of remedy, the company asks the arbitral tribunal to order Australia to suspend the enforcement of the plain packaging legislation or, in the alternative, to pay Philip Morris

\footnotetext{
${ }^{101}$ See eg Robin Hansen, 'Parallel Proceedings in Investor-State Treaty Arbitration', 73(4) Modern Law Review (2010) 523.

${ }_{102}$ Philip Morris Asia Ltd. v. Commonwealth of Australia, Notice of Arbitration under the UNCITRAL Rules (Nov. 21, 2011) [hereinafter Philip Morris - Notice of Arbitration].
} 
compensatory damages for the lost value of its investment 'in an amount to be quantified but of the order of billions of Australian dollars.' Uruguay is facing a similar claim by Philip Morris, and the company has threatened parallel suits against other countries debating the merits of plain packaging legislation. ${ }^{103}$

Along the socio-legal continuum, the basic parameters of this case look quite similar to those in $A A P L$ v. Sri Lanka. The claim was brought by a single claimant. It arises out of a governmental act whose negative impact falls upon a small number of individuals (tobacco companies) but which arguably promises positive benefits in the form of improved health to the entire population of Australia. There is every reason to believe that the public health interests of the Australian populace will be defended adequately by the government of Australia in the investment treaty arbitration, and there is little reason to suspect that other tobacco companies lack access to an effective alternate forum in which to challenge the plain packaging law. ${ }^{104}$ Few special accessto-justice concerns therefore arise out of this socio-legal context.

On the territorial front, both the positive and negative impacts of the challenged law fall largely within Australian borders. The legal claims and defenses raised, by contrast, have significant extraterritorial implications. This is because Philip Morris is basing its legal arguments not only on the provisions of the Hong Kong-Australia bilateral investment treaty but also on certain provisions of the WTO Agreement on Trade-Related Aspects of Intellectual Property Rights (TRIPS), the Agreement on Technical Barriers to Trade (TBT), and the Paris Convention for the Protection of Industrial Property. ${ }^{105}$ Australia, for its part, intends to raise defenses arising out of the same WTO and IP treaties and out of the World Health Organization Framework Convention on Tobacco Control (FCTC). Needless to say, many other states besides Australia are parties to these multilateral conventions and therefore have an interest in the manner in which they are interpreted and applied. This is particularly so in a context where the financial liability of a state party to these treaties vis-à-vis a foreign investor in consequence of the enactment of a generalizable public health measure falls to be determined.

These territorial factors give rise to numerous difficult legal and factual questions concerning how the dispute will be resolved. If the right to health qualifies as a widely recognized human right - as numerous international instruments suggest that it is ${ }^{106}$ - then the tribunal should take

\footnotetext{
${ }^{103}$ Julie A. Maupin, 'Public and Private in International Investment Law: An Integrated Systems Approach', 54(2) Virginia Journal of International Law (forthcoming 2014) [hereinafter 'Maupin - Integrated Systems Approach'] at p. 22 (citing and quoting Philip Morris - Notice of Arbitration, ibid., at paras 4.12, 7.3, 8.2, and 8.3; and Philip Morris Asia Ltd. v. Commonwealth of Australia, UNCITRAL, Australia's Response to the Notice of Arbitration (Dec. 21, 2011) [hereinafter Philip Morris - Response to Notice of Arbitration], para 25).

${ }^{104}$ Other major tobacco companies could have potentially brought parallel investment treaty suits against Australia. And even if this were not the case, the claimants' basic legal challenges are cognizable under Australian law, and the Australian courts have built up a strong reputation of impartiality and independence toward both foreign and domestic litigants.

${ }^{105}$ Philip Morris - Notice of Arbitration, supra note 102 at para 6.6.

106 See 'The Right to Health', Fact Sheet No. 31, Office of the United Nations High Commissioner for Human Rights (June 2008), Annex ('Selected international instruments and other documents related to the right to health (in chronological order)'), at: www.ohchr.org/Documents/Publications/Factsheet31.pdf (which lists: 14 international treaties; seven international declarations, norms and other standards; nine general comments and recommendations by treaty bodies; four Human Rights Commission resolutions, and 11 international conference outcome documents discussing the right to health as a basic human right).
} 
care that its ultimate decision does not compromise Australia's or any other country's ability to advance and protect that right in accordance with existing multilateral treaty obligations. In doing so, the tribunal might make overtures to the human rights community by allowing perhaps even soliciting ${ }^{107}$ - and giving real consideration to amicus briefs from public health advocacy groups and from relevant intergovernmental bodies like the World Health Organization.

If, on the other hand, the tribunal is free to determine of its own accord whether or not the right to health constitutes a widely recognized human right, and whether or not that right has any bearing on the instant case, the tribunal may think itself under no obligation to consider the import of Australia's other multilateral treaty obligations. The Hong Kong-Australia investment treaty unfortunately provides no guidance in this regard. Australia's other multilateral treaty partners are thus left to pin their hopes of preserving their own future health-related regulatory policy space against foreign investment claims upon whatever self-directed means of adjusting for these extraterritorial impact considerations the Philip Morris tribunal may choose to deploy. It would surely be preferable, in such circumstances, to provide arbitral tribunals with investment treaty-based interpretive guidance concerning how they should take into account the competing multilateral treaty obligations of respondent states. ${ }^{108}$

Turning to the political continuum, three observations jump out from the underlying fact pattern. The investment here was made in a heavily regulated industry known in advance to be at high risk of ever increasing levels of regulation not only in Australia but around the world. This fact raises anew many of the considerations concerning investors' legitimate expectations discussed in the context of the Abaclat case study above. But there is an important distinction between the two scenarios which suggests that a different set of dispute resolution strategies may be called for in the Philip Morris case. The complained of governmental action in Philip Morris was carried out in ordinary times by a stable, democratic government well-known for its longstanding commitment to good governance and adherence to the rule of law.

This phenomenon of investors lodging regulatory claims against reputable governments is of relatively recent vintage. ${ }^{109}$ Since regulatory claims against respected developed-country

107 It may be argued by some that proactively inviting amicus participation would exceed the authority of an
investment arbitration tribunal. I note, however, that tribunals have indeed extended open amicus invitations in past
cases, even over the objection of claimants, and this has never led to the serious challenge of any subsequent
arbitration award. See e.g. Aguas Argentinas, S.A., Suez, Sociedad General de Aguas de Barcelona, S.A. and
Vivendi Universal, S.A. v. The Argentine Republic, ICSID Case No. ARB/03/19, Order in Response to a Petition for
Transparency and Participation as Amicus Curiae (19 May 2005), paras 25-27, at:
http://italaw.com/sites/default/files/case-documents/ita0815.pdf.
${ }_{108}$ For details of my own recent proposal along these lines, see Maupin - Integrated Systems Approach, supra note
103 , at pp. $52-54$ (suggesting an interpretive clause to be inserted into future investment treaties). For a private
international law perspective leading to the same conclusion, see Henning Grosse Ruse-Khan, 'A Conflict-of-Laws
Approach to Competing Rationalities in International Law: The Case of Plain Packaging between Intellectual
Property, Trade, Investment and Health' $9(2)$ Journal of Private International Law (2013) 309, at 348 (reiterating,
after exploring the potential of private international law techniques, that a substantive law fix initiated by states
would be the better solution).
109 Two of the earlier claims of this sort to gain notoriety include Maffezini v. Spain, ICSID Case No. ARB/97/7,
Award (13 November 2000); and Methanex Corp. v. United States of America, NAFTA (UNCITRAL rules), Final 
governments were not within the original contemplation of the system's creators, ${ }^{110}$ it seems appropriate to ask in what ways they should be handled differently from other types of disputes now that they have indeed arisen. Here too tribunals can employ self-directed case differentiation strategies. They may choose to engage in only a limited, deferential review of government actions, ${ }^{111}$ or they may stay their hands by applying proportionality or balancing tests of the kind developed by other courts and tribunals. ${ }^{112}$ The ultimate effectiveness of such strategies, however, requires their consistent and perhaps mandatory application. ${ }^{113}$

A second observation within the political spectrum concerns the novelty of the claim as a function of the form of the investment: intellectual property and goodwill. As a jurisprudential matter, there have been few if any cases to-date in which investors have requested compensation for a decline in the value of their protected intellectual property and reputation rights independent of any allegation of a concomitant violation of some more traditional property or contract right. Still, many investment treaty texts explicitly protect investments of this type. ${ }^{114}$ This probably explains why there has been little public commentary on the fact that the claims involve intangible rather than tangible property rights.

There is, however, a third political element to the dispute which goes more to audacity than to novelty. Note that the claimants are asking the tribunal to order Australia to suspend the enforcement of a piece of democratically enacted legislation. This is the primary form of relief sought; compensatory damages are requested only in the alternative. The audacity of this remedial request presents the tribunal with a legal justification challenge similar to that faced by the $A A P L$ tribunal discussed above. In Philip Morris, as in AAPL, the question arises whether taking a bold interpretive step (here, ordering final injunctive relief against Australia) would undermine Australia's willingness to abide by the final award. Indeed, one may ask whether such a move would undermine the willingness of democratic states to continue to participate in the international investment regime at all. Beyond counseling self-restraint on the part of the present tribunal, this suggests that future investment treaties should endeavor to spell out the extent of arbitrators' remedial powers more clearly. ${ }^{115}$

Award of the Tribunal on Jurisdiction and Merits (3 August 2005) (both involving claims for compensation arising out of environmental regulations).

${ }^{110}$ On the haphazard historical trajectory of the system, see Maupin - Integrated Systems Approach, supra note 103, at pp. 7-11. A similar account appears in Joost Pauwelyn's contribution to the present volume.

${ }^{111}$ Stephan W. Schill, 'Deference in Investment Treaty Arbitration: Re-Conceptualizing the Standard of Review Through Comparative Public Law', Working Paper No. 2012/33, presented at the Third Biennial Global Conference of the Society of International Economic Law (12-14 July 2012) [hereinafter 'Schill - Deference'], at: http://papers.ssrn.com/sol3/papers.cfm?abstract_id=2095334.

${ }_{112}$ See the references cited supra, note 7.

${ }^{113}$ Private international law scholars have recently shown interest in supplying investment tribunals with conflict-oflaws-based techniques for navigating what they term 'inter-systemic conflicts' between separate public international law regimes (see e.g. Ruse-Khan - Conflict-of-Laws Approach, supra note 108). While these approaches hold promise, they are extremely complicated, and it is doubtful whether they could be applied in a predictable or even fashion by international adjudicators without extensive specialized training.

${ }^{114}$ Including the one invoked here. See Agreement Between the Government of Hong Kong and the Government of Australia for the Promotion and Protection of Investments, Sept. 15, 1993, 1748 U.N.T.S. 385 [the 'Hong KongAustralia BIT'], at art. 1(e)(iv).

115 Some states have taken steps in this direction. See eg art 34 of the US Model BIT (2012), at: www.state.gov/documents/organization/188371.pdf (allowing tribunals to grant either monetary damages or restitution of property, but the latter only at the option of the respondent state, and disallowing punitive damages). 
Taken together, these three aspects of the Philip Morris case present the most salient considerations within the political continuum which necessitate a careful and differentiated approach to the resolution of the dispute. But before leaving this final case study, it is instructive to note also one major item that has so far been omitted from my discussion of the political continuum here: budgetary impact. It may seem surprising that in my analysis a claim 'of the order of billions of Australian dollars ${ }^{116}$ is not primarily noteworthy within the political continuum by reason of its potential drain on state revenues. Admittedly, there may well be a psychological shock factor to the word 'billion' which causes people to pay more attention to billion dollar investment disputes - of which there are nowadays an increasing number. ${ }^{117}$ Viewed in context, however, the numbers become relative. Given the large size of the Australian economy, the Philip Morris claim amounted to 1.22\% of the Australian government's budget in 2011. ${ }^{118}$ This means Australia's total potential compensation bill in respect of its plain packaging law is unlikely to ever exceed 5\% of the government's annual budget, even if Philip Morris succeeds on all of its claims and even if Australia is found liable to compensate all other affected tobacco companies at the same level. ${ }^{119}$

I do not mean to suggest that these are inconsequential numbers in terms of their potential impact on the public fisc or that they should be dismissed out of hand. Quite the contrary; the Philip Morris case additional red flags within the political differentiation continuum by reason of the non-negligible sums involved. It is nevertheless worth keeping in mind that a well-designed international investment law system should be expected to function equitably across countries at different levels of economic development. If the basic function of international investment law is to promote the economic development of poorer countries by encouraging growth-promoting investment flows to those countries, then one should not necessarily expect large claims against wealthy governments to pose the same kind or same degree of political challenges to investment arbitration tribunals as nominally smaller claims against poorer governments. As in all things, context matters. ${ }^{120}$

Drawing together some common threads, the AAPL, Abaclat, and Philip Morris case studies confirm that international investment disputes exhibit highly variegated characteristics and that these variations give rise to distinctive challenges for dispute resolution. AAPL was a path-

\footnotetext{
${ }^{116}$ Philip Morris - Notice of Arbitration, supra note 102 at para 8.3.

${ }^{117}$ See e.g. Vattenfall AB v. Federal Republic of Germany, ICSID Case No. ARB/12/12 (award pending); 'Vattenfall Launches Second Claim Against Germany', Global Arbitration Review (25 June 2012), available at www.globalarbitrationreview.com/news/article/30634/vattenfall-launches-second-claim-against-germany/ (\$18.7 billion claimed); Alyx Barker, 'Belgium Faces ICSID Claim from Chinese Investors', Global Arbitration Review (24 September 2012) (\$2.3 billion claimed); and Occidental Petroleum Corporation and Occidental Exploration and Production Company v. Republic of Ecuador, ICSID Case No. ARB/06/11, Award (5 Oct 2012 ), para 876 (\$1.8 billion awarded) (annulment proceeding pending).

${ }^{118}$ See the World Bank Country Report for Australia (at: http://data.worldbank.org/austrialia), showing general government final consumption expenditures of \$246,489,208,374 in 2011.

${ }_{119}$ Contrast this with the $42 \%$ figure arrived at in the Abaclat case study infra.

${ }^{120}$ For this reason, there may be a greater prospect of domestic 'regulatory chill' inherent in Philip Morris' pending challenge to Uruguay's recently enacted tobacco legislation than in its claim against Australia. Still, both cases carry the potential for extraterritorial 'chill' in that they may influence the future regulatory choices of other states that are subject to the same or similar investment treaty obligations. The degree of the chill, however, may be expected to co-vary with the wealth of the country contemplating the adoption of a tobacco plain packaging law.
} 
breaking dispute, Abaclat arose out of an extraordinary crisis, and Philip Morris exemplifies an ordinary regulatory dispute. Three different sets of socio-legal, territorial, and political considerations arise in the three cases. In all three cases, the broad discretion left to investment arbitrators by vague treaty provisions and flexible institutional rules allows them to meet some of the unique challenges posed by each dispute through voluntary, tribunal-led dispute resolution strategies. Yet all three cases underscore that the promise of arbitrator-led efforts to adapt to the requirements of different types of disputes is limited. On the one hand, arbitrator-led efforts are unlikely to generate a consistent set of approaches which treats substantially like cases sufficiently alike. On the other, they run the risk of generating unenforceable awards by failing to treat importantly different cases sufficiently differently. In short, proactive changes to the system will be needed in order to provide arbitrators with the necessary guidance to know how and when to apply differentiated dispute resolution methods to fundamentally different types of disputes. In the final section, I outline some possible avenues of exploration along these lines.

\section{Conclusion: toward a methodology of differentiation}

The three-dimensional mapping exercise I have proposed above provides a road map for embarking on the journey of dispute differentiation. It identifies key ways in which different investment disputes are similar and dissimilar. In particular, it brings to the fore the specific characteristics of investment disputes that are likely to pose significant challenges to investment arbitrators in their quest to render awards that not only dispense justice to the disputing parties but also contribute to the efficacy, stability, and fairness of the system as a whole. The analysis can inform the content of the next generation of investment treaties by suggesting how those treaties might prescribe different substantive obligations, different compensation standards, different standards of review, and possibly even different dispute resolution forums ${ }^{121}$ to be applied in different types of investor-state disputes in accordance with the different sets of concerns they raise.

Applying some of the insights gleaned from the cases studies in this paper, a treaty could, for example:

- Specify that investors must exhaust their domestic remedies before bringing any regulatory dispute (e.g. of the Philip Morris type) before an investor-state tribunal, and direct arbitrators to then apply a particular standard of deferential review when deciding such regulatory claims. ${ }^{122}$

- Lay down procedural directives for handling mass claims; or alternatively disallow them.

\footnotetext{
${ }^{121}$ Some disputes may be better left to the domestic courts, or to domestic courts followed by a limited and deferential arbitral review once domestic remedies have been exhausted. Other disputes may be better suited to mediation (perhaps followed by arbitration). Others still may be appropriate candidates for direct recourse to international arbitration.

${ }^{122}$ Perhaps of the type suggested by Schill - Deference, supra note 111.
} 
- Stipulate a special set of procedures to be applied in cases where multiple claims arise out of the same set of facts or circumstances (as in the Argentine crisis cases). ${ }^{123}$

- Set a total compensation ceiling that bears a reasonable relationship to the host state's ability to pay without provoking major domestic political or social upheaval.

- Assign particular compensation methods to particular types of claims, e.g. fair market value for direct expropriation claims, but only actual investment value or reliance value for violations of certain other treaty standards. ${ }^{124}$

- Clarify whether sovereign debt claims may be arbitrated under investment treaties, and if so, when and how.

- Require all claims arising out of investor-state contracts to go through the contractuallystipulated dispute resolution mechanisms before any residual claims can be brought on the basis of an investment treaty, ${ }^{125}$ and require that all claims involving a direct public service sector be arbitrated transparently at every stage (including in any contract-based arbitration proceedings). ${ }^{126}$

- Carve out certain types of governmental measures which may never be subject to an investment treaty claim ${ }^{127}$ or which require the prior approval of all states party to the treaty in question before any specific claim in respect of those measures may proceed to arbitration. $^{128}$

Some of these suggestions will no doubt seem radical to many investment arbitration practitioners and scholars. This is only because we have become used to allowing arbitrators to determine the trajectory of the system in recent years. If one takes the outside perspective, however, the reform possibilities generated by the differentiation analysis are actually quite a bit less radical than the idea that an ad hoc tribunal consisting of a German, a Swiss, and a Canadian

\footnotetext{
${ }^{123}$ Some arbitral institutions have recently adopted and/or are considering rules for handling mass claims and parallel claims. These efforts are laudable, but their utility is limited by the fact that such rules can only be applied with the consent of all of the disputing parties - which is difficult to obtain once a dispute has arisen. A treaty clause, by contrast, could make the application of such procedures mandatory.

${ }^{124}$ In addition, more specific guidance on when it is appropriate to apply the Discounted Cash Flow valuation method, as opposed to other methods like net book value, is desirable.

${ }^{125}$ Even in the presence of a so-called 'umbrella clause'. The need for clarification on this point has been evident since the conflicting decisions in SGS Société Générale de Surveillance S.A. v. Islamic Republic of Pakistan, ICSID Case No. ARB/01/13 (Decision on Jurisdiction) (6 August 2003), paras 146-74; and SGS Société Générale de Surveillance S.A. v. Republic of the Philippines, ICSID Case No. ARB/06/6 (Decision on Jurisdiction) (29 January 2004), paras 92-98, 113-55.

${ }^{126}$ On this point, see the discussion of the Suez case, supra note 14 and accompanying text.

${ }^{127}$ Note that the much-touted interpretation set forth in Annex B to the 2012 US Model BIT stops short of a full carve-out. The relevant portion of that Annex states, in para 4(b): 'Except in rare circumstances, non-discriminatory regulatory actions by a Party that are designed and applied to protect legitimate public welfare objectives, such as public health, safety, and the environment, do not constitute indirect expropriations.' This exception is not general, because it applies only to expropriation claims (not fair and equitable treatment or other types of claims). It is also not full, since it still allows claims 'in rare circumstances' without specifying what those circumstances might be.

${ }^{128}$ Article 31 of the 2012 US Model BIT provides an example of how such a provision might be drafted.
} 
arbitrator should determine whether Australia is allowed, or can afford, to move forward with enforcing its democratically enacted tobacco laws. ${ }^{129}$ They are less radical than accepting, without further deliberation, that private arbitration processes should displace international cooperation efforts in determining how sovereign debt crises can and should be resolved. ${ }^{130}$ They are less radical than granting international arbitrators unfettered discretion ${ }^{131}$ to set the price an embattled government must pay in order to put down a separatist movement within its sovereign territory.

In fact, addressing the international investment regime's present challenges through a differentiated approach entails less radical outcomes and lower transition costs than many of the other proposals that have been put forth to-date. A differentiated approach can respond to the complexities of investor-state disputes without abolishing the entire investment arbitration system, or alternatively, multilateralizing it under a single investment treaty or world investment court. ${ }^{133}$ The approach also spreads the burden of reform more equitably by highlighting that investment arbitrators cannot be expected to cure all of the system's socio-legal, territorial, and political ills on their own. It reminds us that it is incumbent upon everyone who is involved in the international investment law apparatus - including institutional personnel, domestic reviewing courts, civil society critics, academics and most especially those who are responsible for drafting investment treaties, statutes and investor-state contracts - to continually strive to improve the functioning of the system through all available means. ${ }^{134}$

Finally, the differentiation perspective both explains why the anti-investment law 'backlash' movement has steadily gained ground in recent years ${ }^{135}$ and predicts that it is likely to continue to do so if no systemic reforms are forthcoming. ${ }^{136}$ Indeed, the principal insights to be gleaned

${ }^{129}$ These are the nationalities of the members of the Philip Morris v. Australia tribunal, whose names are listed on the website of the Permanent Court of Arbitration. See http://www.pca-cpa.org/showpage.asp?pag id=1494.

${ }^{130}$ See the Abaclat discussion, supra note 76 and accompanying text.

${ }^{131}$ This calls to mind Ronald Dworkin, Taking Rights Seriously (1977) 31 ('Discretion, like the hole in a doughnut, does not exist except as an area left open by a surrounding belt of restriction.') My position is not that investment arbitrators should have no discretion, but that the doughnut hole left open to them in deciding how to calculate compensation is at present too large. Moreover, there should be different doughnuts for different types of investorstate disputes.

${ }^{132}$ See the $A A P L$ case study infra.

133 This is fortuitous, since neither of those options seems particularly feasible at present.

${ }^{134}$ For an argument along these lines, see Ronald Dworkin, 'A New Philosophy for International Law', 41(1) Philosophy \& Public Affairs (2013) (published posthumously) (arguing that all responsible decision-makers have a duty to continually strive for the moral betterment of the international legal order). In my view, this moral duty exists independently of, though fortuitously coincides with, the financial and other self-interests of arbitrators, counsel, institutional personnel, and scholars in preserving the system.

135 Relevant developments have included: the withdrawal of several states from the ICSID Convention; the Australian government's 2011 decision to eschew investor-state arbitration in its future investment treaties; announcements by the South African and Venezuelan governments that they intend to terminate all of their existing investment treaties; and the 'Public Statement on the International Investment Regime', Osgoode Halle Law School (31 August 2010) (in which 50 academics opined that '[ $\mathrm{t}$ ]here is a strong moral as well as policy case for governments to withdraw from investment treaties and to oppose investor-state arbitration'), available at http://www.osgoode.yorku.ca/public_statement /. For scholarly perspectives on some of these developments, see Michael Waibel (ed.), The Backlash Against Investment Arbitration: Perceptions and Reality (2010).

136 Particularly as anti-investment arbitration constituencies become better-informed, better organized, and increasingly vocal. This point was presaged by Christoph Schreuer, 'The Dynamic Evolution of the ICSID System', 17 (Working Paper, delivered in Frankfurt on 26 April 2006) ('So is investor-state arbitration in danger? The answer 
from the very different cases discussed in this paper are twofold. First, the investor-state arbitration system is playing a pivotal role in many of today's most important international governance debates. And second, the one-size-fits-all investment arbitration system of yesteryear is ill-equipped to respond to the important socio-legal, territorial, and political questions raised by the investor-state disputes of today. In short, the international investment law system is in need of an overhaul, and differentiating between different types of disputes along key continuums provides insight into how best to accomplish it.

is probably: not yet but we should not necessarily take it for granted. There may well be further curtailments or even calls to replace the current system by a State v. State system.'), available at www.univie.ac.at/intlaw/pdf/cspubl_86.pdf. Schreuer's analysis has proven prescient. See e.g. Anthea Roberts, 'State-to-State Investment Treaty Arbitration: A Hybrid Theory of Interdependent Rights and Shared Interpretive Authority', 55 Harvard Journal of International Law (forthcoming 2014), at: http://papers.ssrn.com/sol3/papers.cfm?abstract_id=2315078 (proposing the expanded use of state-to-state arbitration within international investment law). 